\title{
KONTEKSTUALISASI SUFISME BAGI MASYARAKAT URBAN
}

\author{
Rubaidi \\ Universitas Islam Negeri Sunan Ampel, Surabaya - Indonesia \\ e-mail: rubaidi@uinsby.ac.id
}

\begin{abstract}
This paper critically examines the important roles of the presence of Sufism institutions for the urban middle class. Writing taken from research on the Majelis Shalawat Muhammad in Surabaya and Bojonegoro presents constructive thinking as well as the creative practices of the murshid, Gus Kahar and Gus Mustakim. Both managed to "reconcile" between modernity and spirituality. The concept of positive sufism and positive zuhud based on Gus Kahar and Gud Mustakim make a significant contribution as well as a reference for urban middle-class people who are often confused and uncertain in combining Islam and modernity. In accordance with the mission of Islam from the beginning of its birth, Islam (sufism) taught in the Majelis Shalawat Muhammad was felt to liberate its jama'ah from diseases suffered by urban communities such as the reason for being analyzed, disorientated, distorted, and so on.
\end{abstract}

\begin{abstract}
Abstrak: Tulisan ini secara kritis menelaah tentang peran-peran penting hadirnya institusi sufisme bagi kalangan kelas menengah urban perkotaan. Tulisan yang diambil dari riset terhadap Majelis Shalawat Muhammad di Surabaya dan Bojonegoro menampilkan pemikiran konstruktif maupun praksis kreatif mursyidnya, Gus Kahar dan Gus Mustakim. Keduanya berhasil "mendamaikan" antara modernitas dan spiritualitas. Konsepsi sufisme positif dan zuhud positif keduanya memberi kontribusi signifikan sekaligus referensi bagi masyarakat kelas menengah perkotaan yang sering kali galau dan gamang dalam memadukan antara Islam dan modernitas. Sesuai misi Islam sejak awal kelahirannya, Islam (sufisme) yang diajarkan dalam Majelis Shalawat Muhammad dirasakan membebaskan para jamaahnya dari penyakit-penyakit yang diderita masyarakat urban perkotaan seperti teralineasi, disorientasi, distorsi, dan lain sebagainya.
\end{abstract}

Keywords: sufism; Majelis Shalawat Muhammad; positive sufism; positive zuhud

\section{A. Pendahuluan}

Globalisasi dengan ideologi modernisme dan berbagai produk turunannya menjadi tantangan bagi peradaban manusia. Di satu sisi, globalisasi memberi dampak positif bagi umat manusia. Ia membuat pekerjaan manusia semakin 
efisien. Komunikasi tidak terbatas oleh jarak dan waktu. Tetapi, efek globalisasi dalam kehidupan yang serba positivistik membuat manusia kehilangan makna esensial kebermaknaan hidup. Mereka mengalami kekeringan spiritual yang membuat hidup mereka tidak tenang dan diselimuti kegelisahan. Potret kehidupan ini ditemukan di sebagian besar masyarakat yang tinggal di kota-kota besar di belahan dunia, tidak terkecuali di Indonesia.

Kehidupan modern yang serba mekanik dan positivistik di atas berimplikasi pada sistem sosial dan kultur budaya masyarakat perkotaan lapisan menengah yang ditandai dengan menurunnya kualitas spiritual dibandingkan masyarakat pedesaan. Ritual keagamaan hanya tampak di tempat-tempat peribadatan, seperti di masjid, gereja, wihara, pura, dan seterusnya. Ritual keagamaan berhenti pada upacara seremonial yang kering spiritualitas. Di luar itu, kehidupan masyarakat berada dalam lingkungan ekonomi dan perdagangan yang bersiat profan. Realitas ini secara diametral berbeda dengan corak masyarakat pedesaan yang kaya akan tradisi dan budaya berbasis pada spiritualitas agama. ${ }^{1}$ Kemakmuran materi, gaya hidup serba instan, serta kurangnya waktu untuk memelihara kebersamaan dengan keluarga dan bersosialisasi telah mengalienasi manusia modern dari diri mereka sendiri. ${ }^{2}$

Fenomena akhir abad ke-20, khususnya pertengahan 1980-an, para ilmuan menyebutnya sebagai "Zaman Baru" (New Age). Indikator penting era new age ditandai dengan fenomena kebangkitan spiritualitas. Dengan kata lain, kecenderungan Zaman Baru merupakan manifestasi dari kebangkitan spiritual (spiritual renaissance) dalam masyarakat modern. ${ }^{3}$ Kekosongan spiritual yang dirasakan ketika manusia telah mencapai kemakmuran material seolah mengajarkan betapa kebahagiaan sesungguhnya tidak terletak pada simbol material dimaksud, melainkan dalam dimensi yang lebih bersifat rohani (spiritual). Tesis ini seperti yang disinyalir oleh Naisbitt disebut sebagai gejala high-tech high touch. ${ }^{4}$ Artinya, semakin canggih teknologi yang diperkenalkan ke

${ }^{1}$ Abu Ahmadi, Ilmu Sosial Dasar (Jakarta: Rineka Cipta, 2009), 229.

2Martin van Bruinessen dan Julia Day Howell, ed., Sufism and the 'Modern' in Islam, Reviews in Religion \& Theology (Minlib Dallh O.P., 2009), 3, https://doi.org/10.1111/j.1467-9418.2009.00463.x.

${ }^{3}$ Gordon Melton, New Age Almanac (Detroit: Visible Ink Press, 1991); Lucinda Vardey, "Intimations of Spiritual Renaissance," Compass 14, no. 2 (1990).

${ }^{4}$ Haidar Bagir, "Tasawuf di Indonesia," dalam Seminar on Islamic Philosophy and Mysticism, April 2007,30. 
dalam kehidupan modern, manusia justru semakin mencari keseimbangan hightouch, yakni spiritualitas (baca: sufisme), seni, sastra, dan sebagainya. ${ }^{5}$

Kebangkitan sufisme dimaksud menurut Harvey Cox tidak pernah dipredeksi sebelumnya. ${ }^{6}$ Kontekstualisasinya dapat dilihat dengan menjamurnya berbagai kelompok tasawuf di belahan besar kota-kota besar dunia. Sejumlah perusahaan yang bergerak dalam bidang manajemen rohani tumbuh subur bak cendawan di musim hujan. Gedung-gedung mewah di kota-kota besar mulai gemar menyelenggarakan pengajian bersama. Di sejumlah kawasan elit juga kerap diadakan acara dzikir dan majelis tasawuf. Bukan hanya kelas menengah kota saja yang hadir, lebih dari itu, tidak sedikit hadir di antara kaum selebritas, kelompok sosialita, bahkan pejabat negara, politisi, maupun kalangan akademisi.

Dalam perspektif budaya postmodernisme, lahirnya kelas-kelas spiritualitas ini cukup menjanjikan sekaligus mengkhawatirkan. Kekhawatiran ini disebabkan budaya postmodern sering dianggap sebagai budaya yang sarat paradoks dan kontradiksi diri (self contradiction). Di satu sisi, wacana spiritualitas dapat menjadi semacam penjaga gawang "kesucian jiwa" di tengah masyarakat yang sarat gejolak pelepasan hasrat tak terbatas. Namun di sisi lain, spiritualitas juga dikhawatirkan dapat terperangkap dalam mekanisme "mesinmesin hasrat," apabila rayuannya tidak dapat dibendung. Tidak mustahil, menjamurnya kelompok spiritual menjadi sarana komersialisasi dan kapitalisasi spiritualitas belaka. ${ }^{7}$

Melalui perspektif yang lebih inklusif dan sosiologis, Amin Syukur menjelaskan bahwa tasawuf adalah ajaran Islam yang membina akhlak manusia, agar tercapai kebahagiaan dan kesempurnaan hidup lahir dan batin, dunia dan akhirat. Sufi adalah orang yang memiliki sikap-sikap mulia dan menghindari sikap-sikap tercela, sanggup menderita lapar dan dahaga, tetapi bila memperoleh rizki tidak lekat di dalam hatinya. ${ }^{8}$ Sufi yang baik adalah orang yang mementingkan amal-amal saleh untuk memperbaiki kualitas lingkungan hidup.

5John Naisbitt, High Tech, High Touch: Technology and Our Search for Meaning (New York: Broadway Books, 1999), 16.

${ }^{6}$ Naisbitt, 17.

${ }^{7}$ Yasraf Amir Piliang, "Fenomena Sufisme di Tengah Masyarakat Posmodern,” Al-Huda 1, no. 2 (2000): 53-54.

${ }^{8}$ Muhammad Amin Syukur, Menggugat Tasawuf (Yogyakarta: Pustaka Pelajar, 1999), 18-9.

JURNAL THEOLOGIA — Volume 30, No. 1, June 2019 
Ia adalah orang yang sehat, giat bekerja, mencari nafkah bagi kehidupan dunianya. Ia boleh kaya, tetapi kekayaannya digunakan secara proporsional untuk dirinya, keluarganya dan kegiatan-kegiatan pemberdayaan umat. ${ }^{9}$ Singkatnya, tasawuf bukan lagi dianggap sebagai ajaran esoteris yang hanya mementingkan keterbukaan (mukāsyafah) dengan Allah. Untuk mencapainya, seorang sufi harus menjauhi komunitas, hidup lusuh, dan menjauhi segala bentuk urusan dunia serta mendedikasikan diri hanya kepada urusan $u k h r a ̄ w \bar{l}^{10}$

Atas dasar asumsi di atas, tulisan ini didasarkan pada riset terhadap institusi sufisme yang berbasis di Surabaya dan Bojonegoro. Nama institsui sufisme dimaksud adalah Majelis Shalawat Muhammad. Pada awalnya, sebagai mursyid adalah Gus Kahar (1962 - 2015 M). Namun, setelah Gus Kahar wafat pada 2015, sufisme Majelis Shalawat Muhammad ini diteruskan oleh Gus Mustakim (1972 - sekarang) sebagai mursyid. Gus Kahar sendiri menjadi mursyid mewarisi keilmuan gurunya, yakni Gus Syamsu Dhuha (1955 - 2003 M). Gus Syamsu Dhuha yang berlatang belakang etnis China, bukan mendirikan Majelis Shalawat Muhammad, melainkan Majelis Shalawat Kubro. Sebaliknya, Shalawat Muhammad hanya menjadi amalan sirri (rahasia) individu. Tiba di era Gus Kahar, selain mengamalkan Shalawat Kubro, Gus Kahar mendapat mandat menyebarkan Shalawat Muhammad. Di akhir era Gus Kahar sempat membuka Shalawat Adlimiyah. Akhirnya, di era Gus Mustakim harus mengemban 3 (tiga) Majelis Shalawat sekaligus, yakni Majelis Shalawat Kubro, Shalawat Muhammad, dan Shalawat Adlimiyah. Ketiga Shalawat ini diwariskan Gus Syamsu dari gurunya, yakni KH. Muhammad Tamyiz (1920 - 1982 M) yang berdomisili di Pesapen, Surabaya. ${ }^{11}$

\footnotetext{
${ }^{9}$ Haidar Bagir, "Manusia Modern Mendamba Allah," dalam Manusia Modern Mendamba Allah: Renungan Tasawuf Positif(Bandung: Mizan, 2002), 24-5.

${ }^{10}$ Perlu digarisbawahi bahwa stigma psimis terhadap tasawuf klasik ini dilihat dari sisi subjektifitas kaum modern, yang salah satu cirinya pekerja keras, disiplin, dekat dengan teknologi, dan aktif. Wajar, jika manusia modern tidak menyenangi tasawuf yang "menghindari keduniaan." Namun demikian, karena ini hanyalah persoalan cara pandang, maka ada juga orang, setidaknya penganut tasawuf klasik, yang optimis bahwa tasawuf klasik juga dapat menyelesaikan problematika kemodernan, karena tasawuf klasiklah yang justru dapat mengontrol modernisasi. Lihat: Mohammad Damami, Tasawuf Positif dalam Pemikiran Hamka (Yogyakarta: Fajar Pustaka Baru, 2000), 177-81.

${ }^{11}$ Ketiga shalawat, yakni Shalawat Kubro, Shalawat Muhammad, dan Shalawat Adlimiyah berasal dari KH. Muhammad Tamyiz diwariskan kepada Gus Syamsu Dhuha, Gus Kahar, dan Gus Mustakim. Interview dengan Gus Mustakim, di Pandaan, tanggal 20 Desember 2018.
} 
Baik Gus Kahar maupun Gus Mustakim sebagai mursyid yang hidup di era mellenial terbukti mampu menerjemahkan Islam melalui ajaran sufisme secara fleksibel sesuai dinamika masyarakat, khususnya masyarakat perkotaan. Seperti watak pada umumnya spiritualitas sufisme, doktrin keduanya mampu secara ekletis diterima oleh para pengikutnya yang umumnya lapisan kelas menengah perkotaan. Seperti akan dijelaskan pada bagian selanjutnya, keduanya memahami serta menerapkan Islam tidak harus "berbenturan" dengan dimensi modernitas dengan berbagai produknya. Sebaliknya, simbol maupun produk modernitas ditaklukkan melalui spiritualitas Islam, yakni sufisme. Sebagai contoh, simbol modernitas seperti Mall, Hotel, maupun Café dimaknai sebagai produk budaya manusia, bukan sekedar produk modernitas barat. Di Mall, Hotel, maupun Café ini, keduanya selain menikmati sebagai karunia Tuhan, juga menjadi media untuk ngaji bersama para muridnya.

Karena itu, ribuan jamaah keduanya yang terdiri dari lapisan kelas menengah perkotaan merasa enjoy dengan ajaran sufisme yang terbukti mampu "mendamaikan" antara yang "profan-hedonis" dengan sakral. Mereka tidak mengenal istilah-istilah seperti aleniasi, kekeringan spiritual, dekadensi moral, dan seterusnya. Sebaliknya, melalui pendekatan sufisme ini, baik secara teori mapun praktek, menampilkan Islam yang positif. Dengan kata lain, corak sufisme yang dikonstruksi Gus Kahar dan Gus Mustakim kepada para pengikutnya membentuk sufisme positif yang memberi kontribusi positif pula bagi terciptanya harmoni social.

\section{B. Potret Gairah Sufisme bagi Masyarakat Kota}

Di berbagai belahan dunia, kota menjadi destinasi masyarakat untuk satu alasan, yakni survivalitas kehidupan mereka. Parahnya, setiap individu warga terjebak kepada gaya hidup profan hasil dari budaya modernisme. Mereka datang dengan tujuan memperoleh pendidikan, keterampilan, nafkah dengan memasuki lapangan kerja di sektor-sektor informal dan sektor formal. Singkatnya, ideologi modernisme telah merubah secara cepat gaya hidup masyarakat urban menjadi masyarakat metropolis. Terlepas dari siap atau tidak siap menghadapi gelombang transformasi ini, masyarakat perkotaan adalah masyarakat yang terus beradaptasi dengan nilai-nilai baru. Pesatnya perkembangan masyarakat yang hidup di pusat-pusat kota sejak tahun 1970-an melahirkan krisis multi dimensi. Di antara krisis dimaksud antara lain adalah menyusutnya 
sumber-sumber energi, perubahan organisasi keluarga (household composition), perubahan gaya hidup, kesadaran akan keterbatasan sumber daya alam dan lingkungan. ${ }^{12}$ Terkait dengan ini, Viktor Frankl mengatakan;

"Perjuangan untuk menemukan makna hidup adalah motivasi utama manusia dalam menjalani kehidupannya. Makna hidup di sini sungguh sangat berbeda dengan keinginan untuk mencari kesenangan (pleasure principle) dan juga berbeda dengan keinginan untuk mencari kekuasaan (will to power)."13

Akibatnya, sebagian dari mereka memilih jalan pintas untuk keluar dari tekanan tersebut melalui cara-cara deviatif, seperti narkoba, minuman keras, dan bahkan bunuh diri. Namun demikian, tidak jarang dari mereka yang memilih jalan spiritualitas. Spiritualisme memang tidak pernah mati. Bukan hanya karena dia terus diwariskan secara turun-temurun dari satu generasi ke generasi lainnya dengan memegang tradisi, melainkan juga muncul di pusat budaya yang sesungguhnya sedang kencang menuju ke arah yang berbeda. Secara tak terduga, sufisme justru muncul di tengah materialisme modern perkotaan. ${ }^{14}$ Modernitas diakui telah membawa perubahan, baik di bidang sains, teknologi, lapangan hidup, dan perilaku masyarakat perkotaan. Indikator paling menonjol dalam modernisasi adalah kecenderungan materialistik, individualistik, dan hedonistik. Oleh karena itu, tidak mengherankan jika ukuran kemajuan lebih dititikberatkan pada persoalan materi dari pada nilai-nilai spiritual. ${ }^{15}$ Masyarakat kota kini menginginkan serta mendambakan sesuatu yang lebih dari sekadar agama formal yang hanya menjalankan ritus keagamaan yang kering penghayatan.

Menurut Komarudin Hidayat terdapat empat alasan tentang sufisme semakin berkembang di kota-kota besar. Pertama, sufisme diminati oleh masyarakat perkotaan karena menjadi sarana pencarian makna hidup. Kedua, sufisme menjadi sarana pergulatan dan pencerahan intelektual. Ketiga, sufisme

12Muh. Adlin Sila, Sufi Perkotaan: Menguak Fenomena Spiritualitas di tengah Kehidupan Modern (Jakarta: Balai Penelitian dan Pengembangan Agama, Departemen Agama RI, 2007), 6-7.

${ }^{13}$ Mustamir, Metode Penyembuhan dari Langit, Tinjauan Religiopsikomedis tembang Obat Hati (Yogyakarta: Lingkaran, 2008), 48.

${ }^{14}$ Bagir, "Tasawuf di Indonesia," 29.

${ }^{15}$ Harun Asfar, "Konsep Spiritualitas Islam sebagai Pencegah Gejolak Perubahan Sosial," dalam Tasawufdan Gerakan Tarekat, ed. H. Amsal Bakhtiar (Bandung: Angkasa, 2003), 96. 
sebagai sarana terapi psikologis. Keempat, sufisme sebagai sarana untuk mengikuti trend dan perkembangan wacana keagamaan.16 Senada dengan Hidayat, menurut Hosein Nasr, sebagaimana dikutip Rahman, krisis dunia modern bersumber dari Barat sejak zaman renaissance. Sejak saat itu manusia adalah makhluk bebas yang independen dari Tuhan dan alam. Manusia membebaskan diri dari tatanan ilahiyah (divine order) untuk selanjutnya membangun tatanan antrophomorfism, tatanan yang semata-mata berpusat pada manusia yang mengakibatkan putus dari spiritualitas. ${ }^{17}$

Kebutuhan spiritualisme masyarakat urban yang semakin tinggi dibuktikan dengan semakin ramainya pertumbuhan majelis pengajian di berbagai sudut kota. Sebut saja dalam kasus Jakarta, adanya Majelis Rasulullah pimpinan Habib Munzir Al Musawwa, Majelis Dzikir al-Dzikra pimpinan Ustadz Arifin Ilham, Majelis Ta'lim Qur'an, Manajemen Sedekah pimpinan Ustadz Yusuf Mansyur, dan lain sebagainya. Di Bandung terdapat Manajemen Qolbu pimpinan Ustadz Abdullah Gymastiar. Selain halnya kegiatan spiritual berbasis teologis, munculnya pelatihan ESQ yang digagas oleh Ary Ginadjar juga merupakan narasi menarik untuk menjelaskan bahwa kebutuhan spiritual kelas menengah perkotaan kini berusaha untuk menyeimbangkan kebutuhan rohani dan juga materi. Di samping itu, munculnya gerakan maupun juga perilaku spiritual keagamaan seperti halnya Anand Khrisna melalui Brahma Kumaris, Lia Aminuddin dengan Komunitas Eden, maupun kemudian munculnya komunitas religius lainnya menandakan bahwa kebutuhan spiritualitas penduduk perkotaan mengalami peningkatan. ${ }^{18}$

Munculnya berbagai macam ekspresi religuisitas yang ditampilkan oleh masyarakat perkotaan selain dimaknai sebagai bentuk peningkatan religiusitas, juga dapat dimaknai sebagai bentuk rekonstruksi agama. Gejala tersebut sebenarnya merupakan bentuk dari rekonstruksi baru mengenai makna ketuhanan di tengah modernitas. Naisbiit (1999) dalam Megatrends dan juga

\footnotetext{
160man Fathurahman, "Urban Sufism: Perubahan Dan Kesinambungan Ajaran Tasawuf," Indonesian Islamic Philology, 2007, http://oman.uinjkt.ac.id/2007/01/urban-sufism-perubahandan.html.

${ }^{17}$ Fazlur Rahman, Islam (Bandung: Pustaka, 1984), 16.

${ }^{18}$ Julia Day Howell, "Pluralist Current and Counter Currents in The Indonesian Mass Media: The case of Anand Khrisna," dalam Religious Pluralism, State and Society in Asia, ed. Chiara Formichi (New York: Routledege, 2014), 217.
} 
High Tech High Touch menyebutkan bahwa kemajuan teknologi yang berkembang telah membuat manusia modern menjadi gamang. ${ }^{19}$ Ketika pemujaan teknologi menjadi besar dan arus utama logika rasional menjadi utama menyebabkan manusia itu kering imannya. Adanya rekayasa genetika dan teknologi yang menjadi ikon manusia modern dalam menyelesaikan masalah justru tidak menemukan solusi yang kuratif. Pada intinya, Naisbit ingin berkata seberapa nalar rasional manusia itu berkembang, akan tidak mampu untuk mengalahkan kekuasaan Tuhan. Menurut Ewert Cousins, salah satu fenomena khas dari bagian akhir abad ke-20 menjelang abad ke-21 ditandai dengan meningkatnya spiritualitas dengan tujuan menyinari masalah yang ditimbulkan oleh modernitas. Para guru spiritual dari Timur yang datang ke Barat mampu menjawab kerinduan spiritual yang mendalam dari banyak orang Barat. Sejak itu, publikasi-publikasi mulai bermunculan seputar kebijaksanaan spiritual (wisdom). ${ }^{20}$

Di kota-kota besar di dunia sekarang ini telah muncul gairah baru pada spiritualitas. Fenomena ini membuktikan bahwa ajaran sufisme kembali diminati oleh masyarakat Islam di zaman modern, termasuk di Indonesia. Budhy Munawar Rachman dengan risih menyebut fenomena haus spiritual sebagai gejala "demam tasawuf." Fenomena ini sebagai antitesis dari kecenderungan umat Islam yang selama ini lebih mengedepankan dimensi ajaran yang serba-fiqh. ${ }^{21}$ Tasawuf dapat dipraktikan di setiap langkah kehidupan. Tasawuf tidak lagi identik dengan domain masyarakat tradisional pedesaan semata seperti dipahami selama ini. Sejak masuknya Islam, sufisme berjasa besar bagi Islam Indonesia. Catatan sejarah ini membuktikan ketiadaan perbedaan antara pemeluk Islam di pedesaan maupun di perkotaan. ${ }^{22}$ Munculnya kecenderungan yang besar terhadap dimensi sufisme membanggakan. Langkah ini merupakan sebuah pengakuan yang jujur akan kembalinya ajaran tasawuf di tengah-tengah kehidupan masyarakat modern perkotaan yang

\footnotetext{
${ }^{19}$ Naisbitt, High Tech, High Touch.

${ }^{20}$ Ewert Cousins, "Hakikat Keyakinan dan Spiritualitas dalam Dialog Antaragama," dalam Agama untuk Manusia, ed. Ali Noer Zaman (Yogyakarta: Pustaka Pelajar, 2000), 77.

${ }^{21}$ Budhy Munawar-Rachman, "Spiritualitas: Pendekatan Baru dalam Beragama," dalam Agama di Tengah Kemelut, ed. Komaruddin Hidayat (Jakarta: Mediacita, 2001), 48.

22 Sila, Sufi Perkotaan. 3.
} 
sebelumnya banyak dikritik karena dianggap menyebabkan kemunduran umat Islam. $^{23}$

Fenomena sufisme di kalangan masyarakat perkotaan atau yang dikenal dengan urban Sufism, dari waktu ke waktu selalu menarik untuk diamati. Bukan hanya dari sisi jumlah pengikut yang selalu bertambah karena ketertarikan pada ajaran Islam esoterik ini. Fnomena urban sufisme dalam wujudnya, seperti Zamhari dan Julia Howell, ${ }^{24}$ dapat dilihat dalam 2 (dua) bentuk, yakni, Pertama, meneruskan tradisi tasawuf yang melembaga (institutionalized) melalui ordonasi sufi yang dikenal dengan istilah tarekat. ${ }^{25}$ Kedua, gerakan sufi atau tasawuf yang tidak formal dalam bentuk majelis shalawat, majelis dzikir, atau majelis taklim, dan sejenisnya. Di kota-kota besar seperti Jakarta, Bandung, Semarang, Yogyakarta, Surabaya, dan sebagainya, fenomena urban sufisme dengan mudah dapat dijumpai di setiap sudut kota tersebut. Pada ordonasi sufi dalam bentuk tarekat memang memiliki struktur organisasi hingga di lintas kota besar tersebut.

Fenomena gairah spiritual masyarakat perkotaan pada masa sekarang sebenarnya bukan hal baru. Dalam historisitasnya, tradisi tasawuf atau tarekat sangat dekat kapada tradisi perkotaan (urban). Pusat-pusat tarekat sejak awal kemunculannya berkembang di sejumlah kota, seperti Baghdad, Bashrah, dan Damaskus. Tarekat yang memiliki pengikut terbanyak di dunia Islam sekaligus tarekat tertua, yakni tarekat Qadiriyah tumbuh dan besar di jantung peradaban Islam waktu itu, yakni Bagdad. Meskipun Syekh Abdul Qadir al-Jaelani lahir di Jilan, tapi ia belajar dan berkembang di kota Baghdad. Di sinilah dia berhasil menapaki jalan spiritual di bawah bimbingan gurunya, al-Dabbas (w.1191). Sejak tahun 1127 dia mulai berceramah di depan umum dan pengikutnya tumbuh secara mantap. Pada tahun 1134 dia dilantik sebagai kepala sebuah

${ }^{23}$ Azyumardi Azra, Konteks Berteologi di Indonesia: Pengalaman Islam (Jakarta: Paramadina, 1999), 120.

${ }^{24}$ A. Zamhari and Julia Day Howell, "Taking Sufism to the Streets: Majelis Zikir and Majelis Salawat as New Venues for Popular Islamic Piety in Indonesia," RIMA: Review of Indonesian and Malaysian Affairs 46, no. 2 (2012): 47-75.

${ }^{25}$ Tarekat sendiri dapat dipilah menjadi 2 (dua) kelompok, yakni (1) Tarekat Muktabarah dan (2) Tarekat Ghairu Muktabarah. Hingga 2005, tarekat muktabarah tercatat sebanyak 44 (empat puluh empat) institusi tarekat. Lihat: Abdul Aziz Masyhuri, Permasalahan Thariqah: Hasil Kesepakatan Muktamar \& Musyawarah Besar Jam'iyah Ahlith Thariqah al-Mu'tabarah Nahdlatul Ulama, 1957-2005 M (Surabaya: Khalista \& Pesantren al-Aziziyyah, Denanyar Jombang, 2006). 
madrasah, tempat orang mulai tertarik kepada kekuatan ceramahnya, sehingga sebuah ribat dibangunkan untuknya di dekat gerbang kota. ${ }^{26}$ Dari fakta ini dapat dipahami, perkembangan ribat yang dipimpinnya lambat laun memperoleh pengikut yang kian banyak berkat ketokohannya serta posisi pusat penggemblengan kaum sufi itu yang berada di kawasan kota. Pada saat itu Baghdad belum jatuh ke tangan Mongol, dan meskipun kekuatan politik Baghdad sudah mulai menyusut, namun pamornya sebagai pusat akademik dan kebudayaan Islam masih tetap kokoh. Para penuntut ilmu dari berbagai penjuru selalu ramai mengunjungi Baghdad untuk belajar kepada para ulamanya, sebelum kemudian mereka menjadi ulama yang menggantikannya. Kiranya tidak berlebihan jika disebut tarekat Qadiriyah sebagai "tarekat kota". Penilian serupa diberikan oleh Gibb demikian; "The most typical urban orders is that of Qadiriya, named after Abd al-Qadir al-jilani or Gilani".27

Fenomena tentang cikal bakal, lahir dan tumbuh berkembangnya ajaran sufisme maupun tarekat di atas secara jelas membuktikan bahwa tarekat awalnya tumbuh di kawasan perkotaan, yang mencerminkan budaya kosmopolitan. Meskipun sekarang ini di Indonesia keberadaan tarekat lebih banyak diikuti oleh penduduk pedesaan, pada awalnya pusat tarekat tetaplah di kota. Secara lebih khusus, Tarekat Qadiriyah wa Naqsabandiyah (TQN) sebagai tarekat yang paling luas pengaruhnya di Indonesia, awalnya berpusat di kota suci Makkah. Tarekat ini dipopulerkan oleh Syekh Ahmad Khatib Sambas (1805-1878) di Makkah sebagai pusat pendidikan Islam dan pencetak ulama. Ia adalah murid Syekh Shams al-Din, murshid tarekat Qadiriyah, yang kemudian berhasil menapaki jalan tarekat ini hingga layak memperoleh sebutan sebagai murshid kamil mukammil. Dari pusat kota Makkah inilah kemudian TQN tersebar ke berbagai wilayah Indonesia melalui 3 khalifahnya yaitu, Syekh 'Abd al-Karim Banten, Syekh Tolhah Cirebon, dan Syekh Wahab Hasbullah Madura. ${ }^{28}$

Selain kota Makkah dikenal sebagi pusat dinamika awal pertumbuhan Tarekat Qadiriyah wa Naqshabandiyah, sudah sejak lama tarekat ini memiliki jaringan kuat di kota ini. Tokoh yang sering disebut-sebut adalah Abdullah al-

26Fazlurrahman, Islam (Chicago: University of Chicago Press, 1979), 158.

${ }^{27}$ H.A.R. Gibb, Mohammadenism (London: Mc.Millan, 1969), 105.

28Zulkifli, Sufism in Java The Role of the Pesantren in the Maintenance of Sufism in Java (Jakarta: INIS, 2002), 15-7. 
Arjinjani (dari Erzincan Turki Tengah) yang telah membangun sebuah zawiyah di Jabal Abu Qubais, dan mempunyai beberapa murid dari Indonesia. Sulaiman al-Qirimi dan Sulaiman Zuhdi juga dipandang sebagai pemimpin yang mewarisi dinamika zawiyyah di kota suci, khususnya yang terakhir, dikenal sebagai Syekh Jabal Abu Qubais atau Syekh Jabal. ${ }^{29}$ Dengan data ini dapat dipastikan bahwa Makkah benar-benar pernah menjadi pusat pertumbuhan tarekat, meskipun tarekat-tarekat tersebut umumnya bukan lahir di rahim tanah suci ini.

Selain kota Makkah, Madinah sebagai pusat kota di Saudi Arabia, di era Islam klasik juga tidak diragukan lagi, merupakan pusat tarekat khususnya, tarekat Sammaniyah yang didirikan oleh Muhammad ibnu 'Abd al-Karim alMadani al-Samman (1718-1775). Dia banyak menghabiskan hidupnya di Madinah, tinggal di rumah bersejarah milik Abu Bakr Siddiq, dan bertindak sebagai penunggu makam Rasulullah. Di tanah air, Tarekat Sammaniyah ini kini berkembang di Sulawesi Selatan, Kalimantan Selatan, dan Palembang. Sultan Palembang tercatat memiliki andil dalam pertumbuhan Tarekat Sammaniyah. Tercatat bahwa Sultan Mahmud Bahauddin pada tahun 1776 memberi uang wakaf sebesar 500 real untuk kepentingan zawiyyah tarekat ini di Jeddah, yang selanjutnya juga berfungsi untuk menampung jamaah haji dari Palembang dalam perjalanannya menuju Makkah. ${ }^{30}$ Dengan demikian, jika di abad ke-21 ini, gerakan sufisme lahir kembali di pusat-pusat kota besar di Indonesia sebenarnya bukan fenomena baru. Hanya saja, secara subtansi, terdapat perbedaan antara fenomena sufisme klasik dengan urban Sufism yang samasama tumbuh berkembang di kalangan masyarakat perkotaan. Pada tradisi sufisme klasik, memiliki kedalam system pengetahuan dibandingkan dengan fenomena urban sufisme.

\section{Shalawat Muhammad sebagai Paradigma Sufisme Positif}

Secara subtantif, dimensi ajaran tasawuf dapat mempertemukan dimensi modernitas masyarakat perkotaan. Masyarakat perkotaan yang identik dengan dunia karir, jabatan, kekuasaan, maupun material dapat disenyawakan dengan

\footnotetext{
${ }^{29}$ Martin van Bruinessen, Tarekat Naqsyabandiyah di Indonesia: Survei Historis, Geografis, dan Sosiologis (Bandung: Mizan, 1992), 67.

${ }^{30}$ Sri Mulyati dan Amsal Bakhtiar, Mengenal dan Memahami Tarekat-tarekat Muktabarah di Indonesia (Jakarta: Kencana, 2011), 53-6.
}

JURNAL THEOLOGIA — Volume 30, No. 1, June 2019 
dimensi sufisme. Majelis Shalawat Muhammad menawarkan paradigma sufisme positif melalui Gus Kahar dan Gus Mustakim sebagai mursyid dengan membagi dimensi "gaya hidup" para guru maupun pengikutnya dalam dua terminologi; Sufisme negatif dan sufisme positif. Pembagian kedua terminologi sebenarnya tidak terlaku kaku, rigid, tetapi lebih bersifat fleksibel. Pembagian ini lebih memudahkan dalam memahami hakikat kehidupan sufisme yang direpresentasi oleh para sufi dan pengikutnya. Sebab, menurut Gus Kahar, inti dari subtansi ajaran tasawuf adalah wusul (bertemu Allah), bukan dibatasi oleh, baik sufisme negatif maupun positif sekalipun.

Menurut Syukur, melalui tasawuf, agama adalah pintu masuk menuju penyelesaian problematika kemodernan. Menyelesaikan problematika modernitas dengan agama (baca: fiqih) saja tidaklah cukup. Karena agama cenderung diaplikasikan secara formalistik dan legalistik seraya melupakan unsur haqiqinya. Karena itu, problematika modernitas ini harus diselesaikan pendekatan sufisme. Sebab, sufisme mengajarkan moralitas yang akan mengangkat manusia ke tingkatan șafä' al-Tawhìd. Pada tahap inilah manusia akan memiliki moralitas Allah (al-Takhalluq bi akhlāq Allāh). Manakala seseorang dapat berperilaku dengan perilaku Allah tercipta keselarasan dan keharmonisan antara kehendak manusia dengan irādah-Nya. Di sinilah peran sufisme dalam mewujudkan harmoni social akan dirasakan masyarakat.

Sufisme negatif maknanya seperti yang dipersepsikan mainstream umat Islam. Bahkan, di kalangan para pengikut sufi sekalipun sering terjebak dalam pemahaman sufisme negatif ini. Sufisme dipersepsikan sebagai ajaran yang mendewakan guru. Karena itu, ajaran ini terjebak kepada kesesatan alias syirik. Selain itu, sufisme distigma sebagai yang anti kemapanan. Asumsi yang berkembang luas, sufisme menolak modernitas sebagai lambang kemajuan, karena kehidupan mereka lebih identik uzlah, ${ }^{31}$ kesederhanaan, dan apatis terhadap lingkungan sosial. Stigma ini yang disebut dengan sufisme negatif. Dalam epistimologi sufisme, sufisme negatif sebagai terminologi tidak lain adalah station, yakni suatu tangga yang harus dilalui untuk mencapai sufisme positif. Secara prinsip, ajaran esoterisme sufi menghendaki hidup aktif dan terlibat

${ }^{31}$ Dalam terminologi sufisme terdapat ajaran uzlah, yakni suatu tahap dimana para murid menjauh dari keramaian masyarakat seraya menyendiri dengan memperbanyak dzikir atas petunjukguru. 
dalam sosial kemasyarakatan. Sesekali melakukan uzlah ada baiknya, tetapi bukan dilakukan terus-menerus. Senada dengan pendapat Gus Kahar, Haedar Bagir dengan sufisme positifnya mengatakan bahwa sufisme yang baik adalah orang yang mementingkan amal-amal sholeh untuk memperbaiki kualitas lingkungan hidup. Ia adalah orang yang sehat, giat bekerja, mencari nafkah bagi kehidupan dunianya. Ia boleh kaya, tetapi kekayaannya digunakan secara proporsional untuk dirinya, keluarganya dan social empowering bagi masyarakat lemah. ${ }^{32}$

Refleksi perjalanan salik menuju wusul meminjam istilah Durkheim dibedakan ke dalam: 1) Pengalaman yang suci (the sacred) dan 2) Pengalaman yang biasa (the profane). Kedua pengalaman tersebut dikategorikan sebagai pengalaman sakral atau iman dan pengalaman sekular. Kedua pengalaman tersebut berbeda satu sama lain. Bahkan, dalam aspek tertentu bertentangan. Durkheim menempatkan pengalaman sakral di atas pengalaman sekular, martabatnya lebih tinggi. Menurut Durkheim pengalaman yang sakral mempunyai ciri-ciri spesifik. Pertama, pengalaman itu menyerukan suatu pengakuan atau kepercayaan pada kekuasaan dan kekuatan supra-natural yang menjadi inti dari sikap keberagamaan atau ketakwaan. Kedua, pengalaman sakral biasanya bersifat samar dan berwajah ganda; bersifat fisik sekaligus moral, bersifat manusiawi tetapi juga bersifat kosmik, beraura positif sekaligus negatif, memiliki jiwa pengasih sekaligus pembenci, menarik dan sekaligus menyebalkan, bersifat menolong dan sekaligus membahayakan manusia. Ketiga, pengalaman sakral pada dasarnya tidak bersifat utilitarian yang mengandalkan prinsip untung dan rugi. Keempat, pengalaman sakral biasanya bersifat nonempiris dan tidak terlalu melibatkan ilmu pengetahuan (scientific knowledge) yang dihasilkan melalui berbagai metodologi penelitiannya. Kelima, pengalaman yang sakral bersifat mendukung, memberi kekuatan, menanamkan rasa hormat yang luhur serta mendatangkan kewajiban etis bagi mereka yang mengalaminya. ${ }^{33}$

Sufisme negatif dalam pandangan Gus Kahar sesungguhnya dimaknai sebagai perjalanan awal para sufi. Sebagai fase perjalanan (baca: pendidikan),

32Bagir, "Manusia Modern Mendamba Allah," 24-5.

${ }^{33}$ Amatullah Armstrong, Kunci Memasuki Dunia Tasawuf(Bandung: Mizan, 1996), 65.

JURNAL THEOLOGIA — Volume 30, No. 1, June 2019 
tentu saja, tidak berlangsung terus menerus, lebih-lebih menjadi ciri dan identitas sufisme itu sendiri. Seluruh guru besar sufi akan melewati fase ini tanpa kecuali. Bahkan, Rasulullah sendiri juga mengalami fase perjalanan kehidupan seperti ini. Kehidupan Rasulullah yang yatim piatu sejak usia belia adalah potret dari perjalanan ini. Menginjak remaja, Rasulullah juga harus bersusah payah menghidupi diri dengan menjadi pengembala. Di masa dewasa, Rasulullah bekerja membanting tulang ikut saudagar perempuan kaya raya, yakni Khadijah. Simbol dari perjalanan Rasulullah dengan susah payah dilukiskan pada saat beliau uzlah (menyendiri) ke dalam Gua Hira.

Menurut sejarah awal sufisme klasik sejak akhir abad ke-2 Hijriyah, sufisme sudah populer di kalangan masyarakat di kawasan dunia islam, ${ }^{34}$ sebagai perkembangan dari gaya keberagaman para zahid dan 'abid berupa kesalehan askestisme yang mengelompok di serambi masjid madinah. Fase awal ini juga disebut sebagai fase askestisme yang merupakan bibit awal tumbuhnya sufisme dalam peradaban Islam. Keadaan ini ditandai oleh munculnya individu-individu yang lebih mengejar kehidupan akhirat, sehingga perhatiannya terpusat untuk beribadah dan mengabaikan keasyikkan duniawi. Fase askestisme ini setidaknya berlangsung sampai akhir abad ke-2 Hijriah. Memasuki abad ke-3 sudah menampakkan adanya peralihan dari askestisme ke sufisme. Fase ini dapat disebut sebagai fase kedua, yang ditandai, antara lain, berupa pergantian zahid menjadi sufi. ${ }^{35}$

Pesatnya perkembangan sufisme, nampaknya memperoleh dorongan setidaknya dari tiga faktor penting, yakni: Pertama, adalah karena gaya kehidupan yang glamour, profane, dan corak kehidupan materialistik-konsumeris yang diperagakan oleh sebagian besar penguasa dan diikuti masyarakat luas. Hidup secara zuhud sebagai reaksi terhadap gaya hidup rezim pemerintahan Bani Umayyah di Damaskus saat itu. Kedua, timbulnya sikap apatis sebagai reaksi maksimal terhadap redikalisme kaum khawarij dan polarisasi politik yang ditimbulkannya. Sikap yang demikian itu melahirkan ajaran 'uzlah yang serukan oleh Surri al-Saqathi (W. 253 H.) sebagai konseptornya. ${ }^{36}$ Ketiga,

\footnotetext{
34'Abd al-Karīm al-Qushayirī, al-Risālah al-Qushairiyah (Kairo, 1330), 138.

${ }^{35}$ Rivay Siregar, Tasawuf: dari Sufisme Klasik ke Neo-Sufisme (Jakarta: Raja Grafindo Persada, 2002), 296.

36Rahman, Islam, 185.
} 
nampaknya, faktor kodifikasi hukum islam (fiqh) dan perumusan ilmu kalam (teologi) yang dialektis-rasional, sehingga kurang bermotivasi etikal yang menyebabkan kehilangan nilai spiritualnya, wahana tiada isi, atau bentuk tanpa jiwa. Karena kondisi hukum dan teologi yang kering tanpa jiwa itu, dihadapkan pada dominannya posisi moral dalam agama, menggugah masyarakat untuk mencurahkan perhatian terhadap moralitas, sehingga memacu pergeseran asketisme kesalehan pada sufisme. ${ }^{37}$

Dalam istilah sufisme, fase awal perjalanan (pendidikan) panjang yang dijalani oleh para guru sufi maupun para pengikutnya melahirkan banyak konsep seperti; zuhud, salik, uzlah, fana,' dan sebagainya. Konsep tersebut begitu kuatnya hingga melekat, bahkan seolah-olah menjadi identitas bagi orang-orang yang masuk ke dalam kehidupan sufisme itu sendiri. Konsep-konsep tersebut dalam pandangan kaum awam dipahami sebagai sufisme itu sendiri. Bahkan, jika terdapat para guru sufi yang hidup jauh dari konsep dimaksud dianggap bukan seorang ahli sufisme.

Berdasarkan gambaran di atas, dalam pandangan Gus Kahar, sufisme pada fase awal ini disebut sebagai sufisme negatif. Sebagai suatu fase perjalanan, sufisme negatif ibarat pemberhentian atau terminal sementara. Sebagai terminal bukan berarti sebagai tujuan akhir, lebih-lebih "gaya hidup." Sebagai pemberhentian sementara berarti terdapat fase perjalanan selanjutnya. Sayangnya, kata Gus Kahar, banyak orang yang terjebak hanya memahami sufisme dalam makna negatif, bahkan memilih sufisme negatif sebagai pilihan "gaya hidup" selamanya. ${ }^{38}$ Seseorang yang sampai kepada "terminal" kedua, yakni sufsime positif, "gaya hidup" seorang guru sufi secara paradok berbeda seperti pada saat masih sampai pada "terminal" pertama. Kontras dengan kehidupan sebelumnya, "gaya hidup" baru yang diperlihatkan kepada publik luas tidak ubahnya seperti masyarakat pada umumnya. Bahkan, "gaya hidup" formal seperti orang kaya, bahkan borjuis. Singkatnya, simbol-simbol kemewahan dunia maupun materi lainnya menjadi bagian yang melekat dan tidak terpisahkan dalam kehidupan paraguru sufi ini.

${ }^{37}$ Siregar, Tasawuf: dari Sufisme Klasik ke Neo-Sufisme, 298.

${ }^{38}$ Disarikan dari Pengajian Majelis Shalawat Muhammad yang diasuh oleh Gus Kahar, di Rumah H. Sukri, Sentul, Tanggul Angin, Sidoarjo, pada 21 April 2015. 
Kisah fase perjalanan kedua menjadi potret di antara para guru sufi di zaman yang berbeda-beda. Syekh Abu Hasan al-Syadzili, seorang guru besar sufi dan pendiri tarekat Sadziliyah, pada fase sufisme positif dikenal sebagai seorang kaya raya. Gaya hidup "glamour" al-Syadzili banyak digambarkan dalam berbagai literatur. Rumah al-Syadzili dihiasi dengan lapisan emas dan permadani. Baju (jubbah) yang dikenakan berlapiskan emas. Tasbih juga terbuat dari emas. Tunggangan sehari-hari adalah kuda pilihan yang sangat mahal. Bahkan, pelana kuda pun juga dihiasi dengan emas. Harta kekayaan al-Syadzili tidak pernah habis meskipun dibagi-bagikan kepada fakir miskin. Contoh kemewahan seperti al-Syadzili juga dijumpai pada sebagian besar guru-guru tasawuf lainnya seperti Syekh Abdul Qadir al-Jailani, Syekh Junaid al-Bagdadi, Syekh al-Ghazali, dan masih banyak lagi.

Gus Kahar mencontohkan beberapa sosok guru tasawuf yang telah melewati "terminal" pertama ini. Gus Kahar lantas menyebut beberapa nama dari mereka, antara lain; Kyai Romli Tamim, Kyai Mustain Romli, Kyai Usman, Surabaya, Kyai Hamid Pasuruan, Kyai Asrori, Surabaya, Gus Syamsu (Guru Gus Kahar), Surabaya, dan masih banyak lagi. Di era 1970-an, pada saat Mobil Mercedes Benz masih menjadi simbol barang super mewah, sosok seperti Kyai Mustain Romli, Kyai Ustman telah mengendarai mobil tersebut. Pakaian jaz berdasi telah lama melekat pada diri Kyai Mustain. Mayoritas masyarakat juga mengetahui secara persis, di balik simbol kemewahan Kyai Mustain, dirinya juga memiliki puluhan ribu santri yang tergabung dalam wadah tarekat Qadiriyah wa al-Naqsyabandiyah. Tentu saja, kehidupan Kyai Mustain, Kyai Ustman, dan banyak guru tasawuf lainnya seperti "melawan arus." Selain "tidak lazim" di kalangan para Kyai hidup dalam simbol yang "glamour," "gaya hidup" seperti mereka ini hanya dialami oleh orang-orang kaya atau para pejabat Negara.

Satu hal yang membedakan antara pelaku sufi dengan mayoritas umat Islam adalah memahami dan menempatkan seluruh atribut duniawi. Pada umumnya, orang menempatkan materi (kekayaan), kekuasaan, serta jabatan sebagai tujuan. Sebaliknya, ibadah para guru sufi tidak mempunyai embel-embel atau tujuan yang bersifat duniawi. Di sini letak perbedaan tentang makna duniawi dalam pandangan dan penempatan antara para guru sufi dan umat Islam pada umumnya. Bagi para guru sufi, atribut duniawi hanya berada di tangan-tangan mereka. Tidak sekalipun materi masuk dalam hati, lebih-lebih menjadikan sebagai tujuan ibadah. 
Dalam dialog dengan gurunya, Gus Kahar mengingatkan, bahwa pilihan "gaya hidup" antara tasawuf negatif dan tasawuf positif sama saja. "Hidup miskin atau kaya adalah sama saja. Keduanya akan sampai kepada Allah dan Rasul-Nya. Kalau hidup kaya bisa sampai kepada Allah, mengapa harus memilih hidup serba miskin?" Tandas Gus Kahar. ${ }^{39}$ Pada awalnya, Gus Syamsu dalam hidupnya memilih hidup "miskin" seperti yang dipilih oleh Mbah Tamyis. ${ }^{40}$ Tetapi, dialog guru-murid, merubah pilihan sang guru. Tahapan tasawuf positif Gus Syamsu berlangsung setelah bertahun-tahun menjalani kehidupan tasawuf negatif dalam bentuk laku suluk (salik) mendampingi sang Guru, yakni Mbah Tamyis. Sebaliknya, Gus Kahar selama puluhan tahun menempatkan diri menjalani tasawuf negatif, mendampingi, mengabdi, serta menghambakan diri dalam kehidupan salik di hadapan Gus Syamsu sebagai gurunya. Hingga masanya tiba, selesai melalui kehidupan tasawuf negatif berganti hidup normal.

Gus Kahar menegaskan, puncak kehidupan tasawuf adalah bertemunya antara fase negatif dan positif. Penggabungan antara tasawuf negatif dan positif akan menghasilkan nur atau cahaya. Ibarat arus listrik, antara (-) dan (+) akan menghasilkan arus listrik berupa cahaya. Makna nur atau cahaya, dalam istilah tasawuf tidak lain adalah Nür Muḥammadiyah atau Nürullāh. Nur inilah puncak dari segala hakikat. Nur atau cahaya seperti ini didapat oleh Muhammad dengan gelarnya "al-Ummi."41 Nur atau cahaya ini tidak lain sesungguhnya adalah

\footnotetext{
${ }^{39}$ Dialog antar guru-murid ini bukan tanpa sebab. Gus Kahar mengingatkan sang guru, meskipun sama-sama suatu pilihan, antara tasawuf negatif dan positif, terdapat alasan mendasar untuk memilih tasawuf positif. Dalam dakwah di zaman modern, tidak cukup menyakinkan orang dengan berbekal kesederhaan saja. Masyarakat membutuhkan bukti terhadap dalil agama, bukan sekedar retorika atau kata-kata. Masyarakat kelas menengah dan atas perlu bukti, bahwa, Islam juga tidak bertentangan dengan modernitas. Dengan bahasa sederhana, Gus Kahar mengatakan, "Aku gak pingin Nabi ku di-cap sebagai Nabi yang miskin," tegasnya.

${ }^{40}$ Mbah Tamyis, lahir di Jombang (tidak diketahui tanggal kelahirannya) dan menetap di Pesapen, dekat Jembatan Merah, Surabaya. Wafat pada 1983. Mbah Tamyis pernah beguru kepada Kyai Romli Tamim Peterongan, Jombang, Kyai Sahlan, Sidoarjo, Abah Toyyib, Kemayoran, Surabaya, Mbah Hasbullah, Boto Putih, Surabaya, dan sebagainya. Mbah Tamyis adalah sahabat dekat Kyai Ustman, Sawah Pulo, Surabaya. Mbah Tamyis adalah salah satu guru spiritual penting dari Gus Mik, Ploso, Kediri, yang tidak banyak diketahui orang.

${ }^{41}$ Makna Ummi yang melekat pada diri Muhammad, dalam tasawuf bukan berarti "bodoh, tidak bisa membaca, atau menulis." Makna ummi adalah puncak dari segala hakekat. Ummi juga dimaknai sebagai puncak dari segala ilmu. Pengetahuan Nabi Muhammad tidak terbatas. Dalam diri Nabi Muhammad ada Nur Muhammadiyah dan nurullah. Karena dalam diri Nabi Muhammad telah menyatu nur Muhammadiyah dan nurullah, maka, tidak ada lagi yang dilihat kecuali Allah. Konsekwensinya, selain dapat menerangi kehidupan umat manusia, juga dapat memahami realitas apapun dalam kehidupan ini.
} 
makna ilmu dalam arti sesungguhnya. Wujud dalam perilaku sehari-hari adalah ahlaq al-Karimah. Ahlaq dimaksud adalah ahlaq Allah dan Rasulullah.

\section{Dari Zuhud Negatif Menuju Zuhud Positif}

Zuhud adalah salah satu maqām (station atau tingkatan) dalam tasawuf yang harus ditempuh para sālik untuk mencapai kemuliaan di sisi Allah. ${ }^{42}$ Salah seorang cendikiawan berkata, "hati akan hidup, jika seseorang mengisinya dengan empat hal, yaitu: ilmu, rị̂a, qana'ah dan zuhud." Dengan ilmu seseorang akan memperoleh riḍa. Sementara, rị̣ā dapat menuntun seseorang menuju qana'ah. Sedangkan, qana'ah dapat mengantarkan seseorang kepada zuhud. ${ }^{43}$ Kata zuhud berasal dari bahasa Arab yang memiliki akar kata zahada-yazhaduzuhdan yang artinya meninggalkan, tidak menyukai dan menjauhkan diri dari. ${ }^{44}$ Menurut Lois Ma'luf, kata zuhud berasal dari bahasa Arab yaitu kata zahada artinya raghaba 'anhu wataraka (benci dan meninggalkan sesuatu), zahada fi aldunyā yang artinya mengosongkan diri dari kesenangan dunia untuk ibadah. Orang yang melakukan zuhud disebut zāhid, zuhhād, atau zāhidūn. ${ }^{45}$

Secara makna, zuhud dapat diartikan suatu sikap yang dijalankan dengan sepenuh hati, bukan hanya dilakukan dengan fisik dan diucapkan dengan lisan saja, akan tetapi berada dalam hati seperti taqwa dan cinta kepada Allah. ${ }^{46}$ Orang yang tidak mencari sebongkah batu padas, dan seember pasir sungai bukanlah seorang zāhid, yang dimaksud seorang zāhid adalah orang yang tidak mencari uang, karena sebongkah batu padas dan seember pasir sungai merupakan bukan barang yang disenangi. ${ }^{47}$ Dengan demikian segala sesuatu yang dilakukannya dalam kehidupan tidak lain hanya dalam rangka mendekat-

${ }^{42}$ al-Ghazali, Ihya' Ulumuddin, ed. Ismail Yakub, 4th ed. (Singapore: Pustaka Nasional Pte Ltd, 1998), 208.

${ }^{43}$ al-Faqih Abu al-Laits al-Samarqandi, Tanbihul Ghafilin: Nasehat bagi yang Lalai, 1 ed. (Jakarta: Pustaka Amani, 1999), 417. 588.

${ }^{44}$ Ahmad Warson, Kamus Arab-Indonesia al-Munawir (Surabaya: Pustaka Progressif, 2002), 296.

${ }^{45}$ Totok Jumantoro dan Syamsul Munir Amin, Kamus Ilmu Tasawuf (Jakarta: Amzah, 2005),

46Muhammad Amin Syukur, Zuhud di Abad Modern (Yogyakarta: Pustaka Pelajar, 2004), 87.

47al-Ghazali, Ihya'Ulumuddin, 205. 
kan diri pada Tuhan. Perilaku ini dalam terminologi sufisme disebut zuhud. ${ }^{48}$ Meskipun banyak pengertian yang diberikan oleh tokoh sufi tentang zuhud, tapi ungkapan para sufi mengarah pada arti deskriptif di atas. Dalam tradisi sufisme, zuhud merupakan maqām yang sangat menentukan kelanjutan ibadah seorang sufi. Sehingga hampir seluruh ahli tasawuf meletakkan zuhud dalam setiap konsep tasawufnya walau dengan konsep yang berbeda.

Al-Ghazālī menempatkan zuhud dalam sistematika: al-tawbah, al-șabr, alfaqr, al-zuhd, al-tawakkul, al-mahabbah, al-márifah, dan al-ridā. Sedangkan alTūsī menempatkan zuhud dalam sistematika: al-tawbah, al-warā', al-zuhd, alfaqr, al-șabr, al-riḍā, al-tawakkul, dan al-ma'rifah. Sedangkan al-Qushayrī menempatkan zuhud dalam urutan maqām yang keenam dari empat puluh sembilan maqām yang dibahas, antara lain: al-tawbah, al-mujāhadah, al-'uzlah, al-taqwā, al-warā', dan al-zuhd. ${ }^{49}$

Jika konsep zuhud dihadapkan dengan ketergantungan terhadap dunia, maka ada dua macam: zuhud ijabi (positif) dan zuhud salabi (negatif), yakni zuhud ijabi hidup bersama masyarakat dan mencari halal saja dalam persoalan kehidupannya tanpa mengharapkan ketinggian kelas di dalam kehidupan bermasyarakat. Zuhud salabi lebih bersifat memutuskan cita-cita (menghindari dunia) sekaligus melemahkan pengharapan. Zuhud ijabi tidak merasakan sikap menjauhi lebih cenderung memberdayakan kesucian jiwa dalam kesendiriannya. ${ }^{50}$ Zuhud menurut al-Taftazani bukanlah kependetaan atau terputusnya kehidupan duniawi, melainkan hikmah pemahaman yang menjadikan para pelakunya mempunyai cara berpikir khusus terhadap kehidupan duniawi, dimana mereka tetap berkerja dan berusaha, akan tetapi dunia ini tidak menjadikan hati mereka cenderung kepadanya, serta tidak membuat mereka mengingkari Tuhanya. ${ }^{51}$

48‘Abd al-Mun'în al-Ḥafnī, Muștalahāt al-Ṣufìyah (Beirut: Dār al-Masirah, n.d.), 121.

49`Abdul al-Karīm bin Ḥawāzin al-Qushayrī al-Naysābūrī, al-Risālah al-Qushayrīyah fi 'Ilm alTașawwuf (Jakarta: Pustaka Amani, 2007), 115.

${ }^{50}$ al-Samarqandi, Tanbihul Ghafilin: Nasehat bagiyang Lalai, 435.

${ }^{51} \mathrm{Abu}$ al-Wafa al-Ghanimi al-Taftazani, Sufi dari Zaman ke Zaman Suatu Pengantar tentang Tasawuf (Madkhal ilā al-Tașawwuf al-Islām), ed. Ahmad Rofi' 'Ustman (Bandung: Pustaka, 1997), 567. 
Dalam tradisi sufisme Gus Kahar maupun Gus Mustakim sebagai mursyid Shalawat Muhammad dan Shalawat Adlimiyah menerapkan tahap zuhud negatif maupun zuhud positif kepada para muridnya secara bersamaan. "Zuhud itu bukan berpakaian compang camping atau menyendiri dari keramaian orang," terang Gus Kahar.52 "Di tempat keramaian seperti ini juga zuhud. Kalau zuhud menyendiri itu mudah. Tetapi, zuhud di Mall atau Café seperti ini yang sulit," tambah Gus Kahar. ${ }^{33}$ Namun demikian, Gus Mustakim menambahkan, bahwa, setiap murid akan menjalankan dua zuhud ini. Lantas, Gus Mustakim menjelaskan proses perjalanan panjang dirinya dan Gus Kahar sendiri selama bertahuntahun menjalankan perintah gurunya tidak lain adalah masa-masa zuhud negatif dimaksud. Dalam tradisi sufisme, proses perjalanan kehidupan zuhud negatif tidak bisa dilepaskan dengan masa menjalankan kehidupan suluk. ${ }^{54}$ Karena itu, kehidupan zuhud negatif melekat pada seorang sālik, seorang murid yang mengikuti jalan (tarekat) guru.

Baik Gus Kahar maupun Gus Mustakim menerapkan metode kedua zuhud ini secara bersamaan terhadap para muridnya. "Awakmu kabeh tidak saya ajari zuhud para ulama zaman biyen. Zuhud ngene wae, tutuke neng pengeran podo wae," terang Gus Kahar.55 "Zamannya sudah berubah, zuhud tidak harus hidup menyepi dan menyendiri di maqam atau yang lainnya," tandas Gus Mustakim. ${ }^{56}$ Motode keduanya dalam menerapkan pendidikan sufisme kepada para muridnya rupanya disesuaikan dengan background maupun status social mereka. Sebagian besar jamaah keduanya merepresentasikan masyarakat perkotaan. Tidak sedikit dari mereka adalah kelas menengah kota. Para pengikut keduanya

\footnotetext{
${ }^{52}$ Dikutip dari pengajian Majelis Shalawat Muhammad Gus Kahar, di Perumahan Puri Indah, Blok AG, no 12, Sidorajo, 15 Juli 2015.

53Sambil minum Kopi di Exelso, Tunjungan Plaza, Surabaya, Gus Kahar menjelaskan hakekat makna zuhud sesungguhnya, yakni selalu menyatu dengan Allah, baik di tempat yang sepi maupun ramai. Disarikan dari ngaji bersama Gus Kahar di Exelso, Tunjungan Plaza, Surabaya, 23 Juni 2015.

${ }^{54}$ Interview dengan Gus Mustakim, mursyid Shalawat Adlimiyah, penerus Gus Kahar, di Pos Ketan, Pandaan, Pasuruan, 12 Desember 2018.

${ }^{55}$ Gus Kahar menerapkan kedua zuhud secara bersamaan, yakni memilih di tempat keramaian seperti Mall maupun Café. Di tempat keramaian ini para muridnya diajari makna zuhud negatif pula, yakni tetap mengosongkon dimensi profan dan hedonistik yang berlebihan. Karena esensi zuhud adalah pengosongan hati dan jiwa dari atribut material. Dikutip dari pengajian Majelis Shalawat Muhammad Gus Kahar, di Perumahan Puri Indah, BlokAG, no 12, Sidorajo, 15 Juli 2015.

56Interview dengan Gus Mustakim, mursyid Shalawat Adlimiyah, penerus Gus Kahar, di Pos Ketan, Pandaan, Pasuruan, 12 Desember 2018.
} 
status sosialnya beragam, mulai kyai (gus), pegawai negeri sipil, TNI/Polri, pengusaha, hingga dosen.

Sebagai guru sufi, baik Gus Kahar maupun Gus Mustakim yang hidup di perkotaan tidak lagi menerapkan model zuhud negatif dalam arti klasik. Hanya beberapa murid tertentu saja yang mendapat amanat itu. Keduanya, memilih mengajarkan zuhud negatif ini dengan metode baru, yakni hidup zuhud di tengah-tengah keramaian masyarakat. Karena itu, fenomena unik pada Gus Kahar maupun Gus Mustakim, di luar rutinitas Majelis Pengajian Shalawat Muhammad dan Shalawat Adlimiyah, lebih banyak menghabiskan waktu di Mall, Café, bahkan Hotel. Di tengah hilir mudik warga kota, baik di Mall, Café maupun Hotel, keduanya masih mengajari para muridnya tentang berbagai hal ajaran hakikat dan makrifat.

Zuhud positif yang dikonstruksi dan dikonseptualisasi, baik oleh Gus Kahar maupun Gus Mustakim semata berusaha menyelaraskan kehidupan masyarakat perkotaan dengan dimensi spiritual Islam. Modernitas dengan berbagai implikasinya tidak harus disalahkan. Keduanya membentuk siklus maupun relasi dialektis. Gus Kahar dan Gus Mustakim tidak pernah menyalahkan, lebihlebih menolak terhadap segala simbol modernitas. Sebaliknya, dimensi modernistas tersebut diisi dengan spiritualitas sufisme. "Menjadi orang iman itu kurang enak apa? Orang Jerman yang membuat Mercy, kita ini tinggal menikmatinya. Tinggal bersyukur saja kok susah kenapa?" Tandas Gus Mustakim. ${ }^{57}$ Selain di Mall, Café, ataupun Hotel, keduanya tidak segan merayakan Ulang Tahun para muridnya. Bahkan, di waktu senggang, keduanya tidak segan bersama para muridnya nonton bioskop di Cinema 21 serta menikmati nyanyi di NAV, Happy Puppy, maupun Inul Viesta. "Saat saya ikut Gus Syamsu pertama kali sering diajak keliling nonton di bioskop Surabaya dan Sidoarjo. Sambil nonton film, Gus Syamsu mengajari caranya dzikir sirri," kenang Gus Kahar sambil mengajari kepada para muridnya bagaimana di tengah keramaian tetap dzikir untuk mengingat Allah. ${ }^{58}$

\footnotetext{
${ }^{57}$ Dialog santai dengan Gus Mustakim, mursyid Shalawat Adlimiyah, di Restoran Fave Hotel, Bojonegoro, tanggal 24 September 2018.

${ }^{58}$ Dialog dengan Gus Kahar, mursyid Shalawat Muhammad, di Starbucks, Ciputra Word, tanggal 18Juni 2015.
} 
Baik Gus Kahar maupun Gus Mustakim tidak pernah mempertentangkan antara sufisme dengan realitas modernitas yang ada. Islam dalam esensinya ada pada sufisme justeru menjadi guiden di tengah realitas kehidupan modernitas tersebut. Anomali, ekses, ataupun implikasi negatif akan selalu lahir dalam dialektika manusia dengan setiap perubahan apapun dalam sejarah manusia. Budhi Munawwar Rahman, menyebutkan bahwa sufisme mempunyai tujuan mendekatkan diri dengan Tuhan, sehingga disadari benar seseorang berada di hadirat Tuhan ${ }^{59}$ Lahirnya sufisme, menurut Amin Syukur diawali dari ketidakpuasan terhadap praktek beragama (Islam) yang cenderung legal-formal. Pendekatan legal-formal dalam prakteknya akan menyalahkan terhadap keadaan yang ada. Sebaliknya sufisme yang mengambil subtansi dapat mendudukkan suatu persoalan sekaligus menjawabnya. ${ }^{60}$ Karena hakikat Islam (sufisme) yang dibawa Nabi Muhammad sejak awal menjawab persoalan umat manusia yang tidak sesuai dengan nilai-nilai ketuhanan.

\section{E. Kesimpulan}

Ideologi modernisme dalam kehidupan masyarakat di era globalisasi, selain memberi banyak implikasi positif bagi tatanan sosial, juga menyisakan ekses negatif bagi sebagian besar mereka. Modernisme dengan mesin utama kapitalisme global selain menciptakan kelas-kelas elit dan menengah baru secara ekonomi juga melahirkan kemisninan struktural di sisi lain. Pada dimensi lain, modernisme di era globalisasi ini melahirkan berbagai kecanggihan teknologi dan informasi yang justeru membuat kehidupan manusia teraleneasi dari kehidupan social mereka. Realitas ini melahirkan ketimpangan dan disparitas sosial yang semakin nyata. Dampak demikian ini dirasakan sebagian besarnya di kalangan masyarakat kota. Akibatnya, sebagai bentuk teraleneasinya masyarakat perkotaan melahirkan anomali kehidupan; budaya hedonism, dekadensi moral, bahkan bunuh diri. Sebagian dari mereka berusaha mencari kembali jatidiri kembali kepada agama.

Proses pencarian jatidiri kembali kepada agama (Islam) umumnya didapatkan pada dimensi spiritualitas Islam yang dikenal dengan sufisme.

\footnotetext{
${ }^{59}$ Budhy Munawar-Rachman, Kontekstualisasi Doktrin Islam dalam Sejarah (Jakarta: Paramadina, 1995), 161.

${ }^{60}$ Syukur, Menggugat Tasawuf, 3.
} 
Karakter dimensi ajaran sufisme yang fleksibel dan menekankan kembali kepada penyucian hati (batin) lebih mengena dibanding dengan ajaran yang hitam-putih sebagaimana doktrin syariat/fiqih. Lebih dari itu, dimensi sufisme lebih menawarkan diskursus keilmuan maupun praktek melalui pendekatan dzikir yang langsung dapat dirasakan oleh pelaku.

Secara generik, konstruksi doktrin sufisme dalam Majelis Shalawat Muhammad yang dipimpin oleh Gus Kahar maupun Gus Mustakim bukan hanya sekedar menawarkan ide-ide baru yang konstekstual dalam keislaman masyarakat urban kota, melainkan dipraktekkan secara nyata. Karena itu, bagi para pengikutnya, Islam yang dikonstruksi oleh sebagian kalangan bertentengan dengan dimensi modernisme ternyata dapat bertemu dengan kehidupan modernitas masyarakat perkotaan. Sebagai contoh, zuhud yang selama dikonstruksi sebagai pola, bahkan pilihan hidup yang harus menjauh dari keramaian, ternyata tidak demikian adanya. Lebih dari itu, ajaran sufisme selama ini difahami sebagai ajaran yang identic dengan anti kemapanan, anti kemajuan, hidup dalam kemiskinan, sesungguhnya juga bertolak belakang. Justeru sufisme mengajarkan tentang keselarasan, keseimbangan, kemajuan, dan berbagai dimensi positif lainnya tanpa harus dipertentangkan dengan ideologi apapun, termasuk ideologi modernisme sekalipun. Lebih dari itu semua, sufisme mengajarkan kepada umat Islam untuk kembali kepada kesatuan wujud, Allah.]

\section{DAFTAR PUSTAKA}

Ahmadi, Abu. Ilmu Sosial Dasar. Jakarta: Rineka Cipta, 2009.

Armstrong, Amatullah. Kunci Memasuki Dunia Tasawuf. Bandung: Mizan, 1996.

Asfar, Harun. "Konsep Spiritualitas Islam sebagai Pencegah Gejolak Perubahan Sosial." dalam Tasawuf dan Gerakan Tarekat, ed. H. Amsal Bakhtiar. Bandung: Angkasa, 2003.

Azra, Azyumardi. Konteks Berteologi di Indonesia: Pengalaman Islam. Jakarta: Paramadina, 1999.

Bagir, Haidar. "Manusia Modern Mendamba Allah." Dalam Manusia Modern Mendamba Allah: Renungan Tasawuf Positif. Bandung: Mizan, 2002. 
-_—. "Tasawuf di Indonesia." dalam Seminar on Islamic Philosophy and Mysticism, 2007.

Bruinessen, Martin van. Tarekat Naqsyabandiyah di Indonesia: Survei Historis, Geografis, dan Sosiologis. Bandung: Mizan, 1992.

Bruinessen, Martin van, dan Julia Day Howell, eds. Sufism and the 'Modern' in Islam. Reviews in Religion \& Theology. Minlib Dallh O.P., 2009. https://doi.org/10.1111/j.1467-9418.2009.00463.x.

Cousins, Ewert. "Hakikat Keyakinan dan Spiritualitas dalam Dialog Antaragama." dalam Agama untuk Manusia, ed. Ali Noer Zaman. Yogyakarta: Pustaka Pelajar, 2000.

Damami, Mohammad. Tasawuf Positif dalam Pemikiran Hamka. Yogyakarta: Fajar Pustaka Baru, 2000.

Fathurahman, Oman. "Urban Sufism: Perubahan dan Kesinambungan Ajaran Tasawuf." Indonesian Islamic Philology, 2007. http://oman.uinjktac.id/ 2007/01/urban-sufism-perubahan-dan.html.

Fazlurrahman. Islam. Chicago: University of Chicago Press, 1979.

al-Ghazali. Ihya' Ulumuddin. terj. Ismail Yakub. 4th ed. Singapore: Pustaka Nasional Pte Ltd, 1998.

Gibb, H.A.R. Mohammadenism. London: Mc.Millan, 1969.

al-Ḥafnī, 'Abd al-Mun'īn. Muștalahāt al-Ṣufìyah. Beirut: Dār al-Masirah, n.d.

Howell, Julia Day. "Pluralist Current and Counter Currents in The Indonesian Mass Media: The Case of Anand Khrisna." dalam Religious Pluralism, State and Society in Asia, ed. Chiara Formichi. New York: Routledege, 2014.

Jumantoro, Totok, and Syamsul Munir Amin. Kamus Ilmu Tasawuf. Jakarta: Amzah, 2005.

Masyhuri, Abdul Aziz. Permasalahan Thariqah: Hasil Kesepakatan Muktamar \& Musyawarah Besar Jam'iyah Ahlith Thariqah al-Mu'tabarah Nahdlatul Ulama, 1957-2005 M. Surabaya: Khalista \& Pesantren al-Aziziyyah, Denanyar Jombang, 2006.

Melton, Gordon. New Age Almanac. Detroit: Visible Ink Press, 1991.

Mulyati, Sri, dan Amsal Bakhtiar. Mengenal dan Memahami Tarekat-tarekat Muktabarah di Indonesia. Jakarta: Kencana, 2011. 
Munawar-Rachman, Budhy. Kontekstualisasi Doktrin Islam dalam Sejarah. Jakarta: Paramadina, 1995.

_- C. "Spiritualitas: Pendekatan Baru dalam Beragama." dalam Agama di Tengah Kemelut, edited by Komaruddin Hidayat. Jakarta: Mediacita, 2001.

Mustamir. Metode Penyembuhan dari Langit, Tinjauan Religiopsikomedis Tembang Obat Hati. Yogyakarta: Lingkaran, 2008.

Naisbitt, John. High Tech, High Touch: Technology and Our Search for Meaning. New York: Broadway Books, 1999.

al-Naysābūrī, 'Abdul al-Karīm bin Ḥawāzin al-Qushayrī. al-Risālah al-Qushayrīyah fi Ilm al-Tașawwuf. Jakarta: Pustaka Amani, 2007.

Piliang, Yasraf Amir. "Fenomena Sufisme di Tengah Masyarakat Posmodern." AlHuda 1, no. 2 (2000).

al-Qushayir,'Abd al-Karīm. al-Risālah al-Qushairiyah. Kairo, 1330.

Rahman, Fazlur. Islam. Bandung: Pustaka, 1984.

al-Samarqandi, al-Faqih Abu al-Laits. Tanbihul Ghafilin: Nasehat Bagi Yang Lalai. 1st ed. Jakarta: Pustaka Amani, 1999.

Sila, Muh. Adlin. Sufi Perkotaan: Menguak Fenomena Spiritualitas di Tengah Kehidupan Modern. Jakarta: Balai Penelitian dan Pengembangan Agama, Departemen Agama RI, 2007.

Siregar, Rivay. Tasawuf: Dari Sufisme Klasik Ke Neo-Sufisme. Jakarta: Raja Grafindo Persada, 2002.

Syukur, Muhammad Amin. Menggugat Tasawuf. Yogyakarta: Pustaka Pelajar, 1999.

——_. Zuhud di Abad Modern. Yogyakarta: Pustaka Pelajar, 2004.

al-Taftazani, Abu al-Wafa al-Ghanimi. Sufi dari Zaman ke Zaman: Suatu Pengantar tentang Tasawuf (Madkhal Ilā al-Tașawwuf al-Islāmī). terj. Ahmad Rofi' 'Ustman. Bandung: Pustaka, 1997.

Vardey, Lucinda. "Intimations of Spiritual Renaissance." Compass 14, no. 2 (1990).

Warson, Ahmad. Kamus Arab-Indonesia al-Munawir. Surabaya: Pustaka Progressif, 2002.

JURNAL THEOLOGIA — Volume 30, No. 1, June 2019 
Zamhari, A., and Julia Day Howell. "Taking Sufism to the Streets: Majelis Zikir and Majelis Salawat as New Venues for Popular Islamic Piety in Indonesia." RIMA: Review of Indonesian and Malaysian Affairs 46, no. 2 (2012): 47-75.

Zulkifli. Sufism in Java the Role of the Pesantren in the Maintenance of Sufism in Java. Jakarta: INIS, 2002. 
